\title{
IAMJ
}

INTERNATIONAL

AYURVEDIC

MEDICAL JOURNAL

Case Report

ISSN: 23205091

Impact Factor: 5.344

\section{ASSESSMENT OF THE EFFICACY OF SPECIFIC YOGASANASA - SINGLE CASE STUDY ON PCOS}

\author{
Sushma $^{1}$, Shivani Chaudhary ${ }^{2}$, Satish Jalihal ${ }^{3}$ \\ 1,23rd year PG scholar, Dept of PTSR, AAMC Moodbidri, Dakshinakannada, Karnataka, India \\ ${ }^{3}$ Associate Professor, Dept of PTSR, SVM Ayurveda Medical College \& Hospital, Ilkal, \\ Karnataka, India
}

Corresponding Author: shivanichaudhary538@gmail.com

\section{https://doi.org/10.46607/iamj15p4052020}

(Published online: July 2020)

Open Access

(C) International Ayurvedic Medical Journal, India 2020

Article Received: 02/07/2020 - Peer Reviewed: 25/07/2020 - Accepted for Publication: 25/07/2020

\section{Check for updates}

\begin{abstract}
Due to sedentary lifestyle and stress, the incidence of metabolic disorders is increasing day by day. Among these, polycystic ovarian syndrome (PCOS) is one of them. PCOS is a disease, which is related to cystic changes in the ovary. The follicles develop from primordial follicle, but the development stops at an early antral stage due to disturbed ovarian function. Women with PCOS have irregular menstrual cycle, excess of androgen, anovulation, acne, hirsutism and infertility. According to Ayurveda, this type of clinical features is found in Pushpagni, Jatahar$n i$ and Artavakshaya. It can be considered as rasa Medodhatuvikara and has to be managed depending on Doshadushya vitiation. Ayurvedic management principles as Amaharachikitsa, Shodhana and Samana therapies along with Vata-Kaphahara Dravyas. Diet and lifestyle modifications are also proving to be beneficial in PCOS. The present study highlights the effect of Samana therapy in PCOS.
\end{abstract}

Keyword: PCOS, Artavakshaya, Anovulation, Samana

\section{INTRODUCTION}

Menstrual cycle is a natural process but due to change in the lifestyle, women are cursed with vari- ous menstrual irregularities, which even lead to secondary amenorrhoea. PCOS is considered to be the 
most common lifestyle disorder, and the worldwide prevalence of PCOS is $6.5-6.8 \%$ according to $\mathrm{NIH}$ criteria ${ }^{1}$. It occurs among all the races and nationalities. It is an endocrine disorder affecting women in their reproductive life. It is an ovarian cause of secondary amenorrhoea which not only hampers the normal menstrual cycle but also has significant affliction on the fertility of the lady. The exact pathophysiology of PCOS is not clearly understood but it can be assumed that PCOS occurred due to excess of production of androgen by the ovaries. Considering the contemporary science, it is known to feature several hormonal disturbances including hyperandrogenemia, insulin resistance and hyperinsulinemia ${ }^{2}$ and accordingly the treatment is given like hormonal therapy, anti-diabetic drugs \& surgical ovarian drilling technique etc., which is of cost effective. Considering the symptoms of PCOS, it can be correlated with Pushpaghni Jaataharini ${ }^{3}$, in this Avastha, there is Avarodha of Pushpa and Vata by the Dushitakapha \& Medas. So, the management in PCOS should be targeted at Agnideepana, Pachana, Vatanulomona and Rasa-Rakta Prasadana.

\section{Case Report}

A female patient aged 22 years attending the outpatient department, presenting with the complain of irregular menstruation and hair fall since 3 years. Before 3 years she didn't get periods for 4 months then she consulted allopathic doctor they advised to do USG. In USG PCOD was diagnosed. She took hormonal treatment for 3 cycles then her period become regular. After completion of 3 months of treatment, next 2 cycle period was normal but after that it became irregular. So, she came for ayurvedic treatment.

Menstrual History: 2-3/ 50-60 days, 2 pads/day, irregular cycle, moderate flow sometime with clots

Personal History: Occupation- housewife, Dietmixed diet, more junk food, Sleep- sound sleep, Bowel-sometimes constipated, Appetite - normal, Micturition - normal, 4-5 times/day

Clinical Examination: Patient well conscious, oriented, hemodynamically stable O/E - PR- 74/min, B.P - 110/70 mm of hg, Ht- $152 \mathrm{~cm}$, Wt- $62 \mathrm{~kg}$, BMI $-26.8, \mathrm{P} / \mathrm{A}-\mathrm{Soft}$, Non tender
Prakriti - Vatakapha, Jaran Shakti, Madhyam, Agnidushti

\section{Investigation}

Hb- 11.6 gm $\%$, TSH - 2.45mIU, Prolactin - WNL, USG - B/L polycystic ovaries, Rt ovary $-16 \mathrm{cc}$, Lft ovary- $14.2 \mathrm{cc}$

\section{Treatment:}

$1^{\text {st }}$ visit- 2-8-2019, LMP- 1-6-2019

1. Gandharvahastadi Kashaya ${ }^{4}+1$ tsp Vilangtanduladi Churna ${ }^{5}$ at 6 am on empty stomach $(15 \mathrm{ml}$ of Kashaya $+80 \mathrm{ml}$ of lukewarm water)

2. Saptasara Kashaya ${ }^{6}+1$ tsp Hinguvachadi Churna $^{7}$ at $6 \mathrm{pm}$ on empty stomach $(15 \mathrm{ml}$ of Kashaya $+80 \mathrm{ml}$ of lukewarm water)

3. Abhayarista + Kumara Asava $(20 \mathrm{ml}-0-20 \mathrm{ml})$ $\mathrm{A} / \mathrm{F}$

4. Tab Chandraprabha Vati 2-0-2 A/F with lukewarm water

5. Astha Churna ${ }^{8} 1$ tsp BD in between food

Treatment given for 2 months with Pathya-AharaVihara (avoid medicine during periods)

$2^{\text {nd }}$ visit 2- 10-2019

$1^{\text {st }}$ LMP $-17-8-2019,2^{\text {nd }}$ LMP 24-9-2019, Repeat same medicine for 1 more month.

$3^{\text {rd }}$ visit 3-11-2019

LMP 22-10-2019

Advised for USG

USG- Both ovaries appear normal in size, rt ovary $9.4 \mathrm{cc}$, 1t ovary- $9 \mathrm{cc}$

\section{DISCUSSION}

PCOS is also the cause of infertility. It is associated with anovulation, excess of androgen, obesity. In this there is increased free testosterone, free estradiol, estrone and androgen. its favouring LH secretion and steady state follicle stimulating hormone levels which effects follicular maturation. This hyperandrogenic, normoestrogenic environment results in anovulatory state. According to Ayurveda in this condition there is imbalance of Vata and Kapha Doshas and SrotoAvarodha. So, the line of management was VataKapha Shamaka, Pitta Vardhaka and DhatavagniVardhan (which improve digestive power and act as Deepana and Pachana. Clinical examination and his- 
tory revealed Dhatuagnimandya, Rasa Dhatudusti, Vata-Kaphavaigunya (abnormal Vata and Kapha Dosha) specially Apanavayuvaigunya. Ghandharvahastadi Kashaya helps to pacify the Vata and acts as Deepana, Pachana and Mala Shodhaka. So, it helps to regulate the Apana Vata and relieve the constipation. Vilangatanduladi Choorna which is mentioned in Ashtang Hrdaya helps to pacify both Vata and Kapha Dosha. Saptasara Kashaya acts as Pitta Vardhaka and helps in Artavajanana. Hinguvachadi Choorna which is indicated in Vridhi Rogas, helps to remove the obstruction in Srotasa. Abhayarista and Kumaryasava helps in Apanavayu Anulomana and regulate the menstruation. Ashtachoorna remove Srotoavrodha and increase the Jatharagni \& Dhatuvagni. Chandraprabha Vati acts as Tridoshahara, Balya, Rasayana and it helps to regulate the hormones.

\section{CONCLUSION}

Depending on basic principle of Ayurveda Dosha, Dhatu, Agni any disease can be diagnosed and treated as well. In this case Ayurveda treatment helped in balance the Doshas and improving ovarian function as well as hormonal function and regularizing the normal menstrual cycle.

\section{REFERENCES}

1. E Diamanti- Kandarakis, Role of Obesity and Adiposity in Poly Cystic Ovary Syndrome, International Journal Of Obesity (2007) 31, Www.Nature.Com.

2. J. Rojas Poly Cystic Ovarian Syndrome, Insulin Resistance and Obesity 2014 Cited By 16, www.hindawi.com

3. Tewari P.V Editor, Kasyapa Samhita Or Vridhajivakaiyatantrakalpasthana, Chaukambhavisvabharti Oriental Publisher and Distributers; Varanasi; 2013, P.357.

4. Sahasrayoga Edited By K.V Krishnan Vaidyar, Vidyarambam Publisher Mullakkalalappuzakerala 2015, Kashaya Prakaranavataharakwatha P.78

5. Ashtangahrdayamvol Ii Translated by Prof K.R Srikanthamurthy, Chowkhambakrishnadas Academy Varanasi 2013, Kalpasidhisthanam virechankalpamsloka No 15,16, P.541
6. Sahasrayoga Edited By K.V Krishnan Vaidyar, Vidyarambam Publisher Mullakkalalappuzakerala 2015, Kashaya Prakaranagulmaharakwatha P.92

7. Ashtangahrdayamvol Ii Translated by Prof K.R Srikanthamurthy, Chowkhambakrishnadas Academy Varanasi 2013, Chikitsasthanamgulmachikitsithasloka No 31,32, P.406

8. Ashtangahrdayamvol Ii Translated by Prof K.R Srikanthamurthy, Chowkhambakrishnadas Academy Varanasi 2013, Chikitsasthanamgulmachikitsithasloka No 35, P.406

\section{Source of Support: Nil Conflict of Interest: None Declared}

How to cite this URL: Shivani Chaudhary et al: Assessment Of The Efficacy Of Specific Yogasanasa - Single Case Study On PCOS. International Ayurvedic Medical Journal \{online\} 2020 \{cited July, 2020\} Available from: http://www.iamj.in/posts/images/upload/2450 2452.pdf 